\title{
Diet and feeding rhythm of the sand-burrowing mysids Archaeomysis kokuboi and A. japonica in Otsuchi Bay, northeastern Japan
}

\author{
Kazutaka Takahashi*, Kouichi Kawaguchi \\ Ocean Research Institute, University of Tokyo, 1-15-1 Minamidai, Nakano, Tokyo 164, Japan
}

\begin{abstract}
Feeding rhythm, in terms of diel change in frequency of occurrence of empty stomachs and in gut pigment content, and composition of diets were investigated for the sand-burrowing mysids Archaeomysis kokuboi and A. japonica during the summer season on a sandy beach at Otsuchi Bay, northeastern Japan. A. kokuboi exhibits pronounced nocturnal feeding regardless of sex or developmental stage. A. japonica also shows nocturnal feeding, although the nocturnal feeding rhythm of the mature mysids is less clear than that of the juveniles due to the increase in daytime feeding with growth. The nocturnal feeding of both species suggests that their previously known inter- and intraspecific habitat zonations during the daytime are not related to their feeding strategies for resources partitioning, but to other factors such as predator avoidance. Mature A. kokuboi mainly ingested planktonic copepods such as Microsetella rosea and Oncaea venusta, while mature A. japonica fed on benthic harpacticoid copepods as well as planktonic copepods. No difference between sexes was recognized in the diets of the 2 species. Juveniles of both species mainly fed on copepod nauplii. There was a maximum of $80 \%$ overlap in the diets of the juveniles of these 2 species. This overlap of diets explains the habitat segregation of juveniles of both species at night in the water column.
\end{abstract}

KEY WORDS: Diet - Feeding rhythm $\cdot$ Mysidacea $\cdot$ Sandy beach $\cdot$ Northeastern Japan

\section{INTRODUCTION}

Mysids belonging to the genus Archaeomysis, subfamily Gastrosaccinae, consist of sand-burrowers found in the temperate and subarctic waters of the North Pacific (Mauchline \& Murano 1977, Jo \& Hanamura 1993, Hanamura et al. 1996). They are abundant in Japanese waters and considered to play an important role in the sandy beach ecosystem (Itô 1985, Takahashi \& Kawaguchi 1995). Two species, A. kokuboi Ii and A. japonica Hanamura, Jo \& Murano, have been recorded in Otsuchi Bay, off the Pacific coast of northeastern Japan, and they are known to show clear inter- and intraspecific zonation in nearshore waters (Takahashi \& Kawaguchi 1995). In

\footnotetext{
- Present address: Department of Bioengineering, Faculty of Engineering, Soka University, 1-236 Tangi-cho, Hachioji 192, Japan.E-mail: issey@t.soka.ac.jp
}

addition, they are known to swim up into the water column nocturnally in species-specific ways (Takahashi \& Kawaguchi 1997). To elucidate the function of such distribution patterns, knowledge of mysid feeding habits is necessary since distribution or migration patterns in many mysids in coastal areas have been reported to often be affected by distribution and availability of food (Clutter 1967, Wooldridge 1989, Webb \& Wooldridge 1990). The density of $A$. kokuboi, an inhabitant of the intertidal zone, is known to be 3 to 21 times as high as that of $A$. japonica, an inhabitant of the subtidal zone, in Otsuchi Bay during the summer season (Takahashi \& Kawaguchi 1995), but what kinds of food support such high densities of A. kokuboi is still unknown. This paper aims to examine the feeding rhythms and diets of A. kokuboi and A. japonica in relation to their habitat segregation during the summer season on a sandy beach in Otsuchi Bay. 


\section{MATERIALS AND METHODS}

All sampling was carried out at Koshirahama Beach, Otsuchi Bay. A detailed description of the study site was given in Takahashi \& Kawaguchi (1995). Samples were taken every $3 \mathrm{~h}$ for $24 \mathrm{~h}$ on 8-9 September 1994. Sunset and sunrise times were 18:07 and 05:20 h, respectively. Sand-burrowing mysids in each category, i.e. mature males, mature females and juveniles, were collected from the center of their habitats, which is different between the 2 species, between each species' developmental stages and between day and night (Takahashi \& Kawaguchi 1995, 1997). Mature male and female Archaeomysis kokuboi were collected with a sledge net $(30 \mathrm{~cm}$ width, $10 \mathrm{~cm}$ height, $330 \mu \mathrm{m}$ mesh size) in the swash zone during the daytime and at night. Juvenile A. kokuboi were also collected with the sledge net in the swash zone during the daytime, but with a conical plankton net $(60 \mathrm{~cm}$ mouth diameter, $330 \mu \mathrm{m}$ mesh size) at a point $20 \mathrm{~m}$ offshore at night. Mature male and female A. japonica were collected with the sledge net at points 20 and $50 \mathrm{~m}$ from the shoreline both during the daytime and at night. Juvenile A. japonica were collected with the sledge net at the point $20 \mathrm{~m}$ offshore, but with the plankton net at the points 20 and $50 \mathrm{~m}$ offshore at night. Samples were frozen with dry ice within 10 min after collection and transferred to a freezer in the laboratory and kept at $-20^{\circ} \mathrm{C}$ and analyzed. A part of samples $150 \%$ of each sample) was preserved in 10\% formalin for the direct observation of stomach contents.

The feeding rhythm was determined by measuring the change in gut (stomach + midgut + hindgut) pigment content of a sample in a time series. In the laboratory the frozen samples were thawed out in filtered seawater and sorted into juveniles, mature males and mature females under a stereo microscope. Standard length $(S L)$ was measured with a profile projector as the distance from the base of the eyestalk to the posterior end of the 6th abdominal segment. The criteria of growth stage categories were primarily based on Mauchline (1980). Juveniles of both species were identified according to Takahashi \& Kawaguchi (1996). Specimens were rinsed with filtered seawater and then dipped into $10 \mathrm{ml}$ of $\mathrm{N}, \mathrm{N}$-dimethylformamide to extract gut pigments (Suzuki \& Ishimaru 1990). The number of mysids in an extraction bottle was 1 to 3 individuals for adults and 5 to 10 individuals for juveniles. Three to 20 extraction bottles were prepared for each developmental stage collected at each time except for juveniles of $A$. japonica at 01:00 h when only 1 extraction bottle was prepared. The extraction bottles were kept at $-20^{\circ} \mathrm{C}$ in darkness until analysis (>24 h later). Pigment concentrations were measured with a Turner Model 111 fluorometer, following the procedure of Yentsch \& Menzel (1963) and Mackas \& Bohrer (1976). The gut pigment content was expressed as chlorophyll a + phaeopigments in chlorophyll a equivalent weight per body carbon weight. Body carbon weight of mysids was estimated from standard length based on the following equations derived from field-collected data (Takahashi 1996).

$$
\begin{array}{rr}
\begin{array}{r}
\text { Archaeomysis kokuboi: } \\
\text { CW }=0.0016 S L^{3.05}
\end{array} & (\mathrm{n}=91, \mathrm{r}=0.987) \\
\begin{array}{r}
\text { Archaeomysis japonica: } \\
C W=0.0022 S L^{287}
\end{array} & (\mathrm{n}=58, \mathrm{r}=0.940)
\end{array}
$$

where $C W$ is carbon weight of mysid $(\mathrm{mg})$ and $S L$ is standard length $(\mathrm{mm})$. When the gut pigment of several individuals was measured at once, their average standard length was used for an estimation of body carbon weight.

Frequency of occurrence of empty stomachs was also measured, since feeding rhythms cannot be detected by the gut fluorescence method when diets or prey organisms contain no chlorophyll a and phaeopigment. At each sampling time, stomachs of 10 to 20 mysids at each developmental stage were analyzed for stomach emptiness.

The diet of mysids was determined using the preserved specimens. Twenty-five to 34 mysids of each developmental stage were dissected to examine stomach contents. Composition of diets was analyzed by the points method which was designed for stomach content analysis of portunid crabs (Williams 1981, Wear \& Haddon 1987). This method assesses the diet composition in terms of stomach fullness and the estimated volume of food items in the stomach and is suitable for assessing diets of crustaceans whose stomach contents are well macerated and hard to quantify. The procedure of the points method is summarized as follows:

The stomach of a mysid was removed and immersed in glycerol on a slide glass, and then the relative degree of stomach fullness was assessed visually. Stomachs were grouped into the 6 classes as follows: $100 \%$ full stomach designated as Class 5; 75\% $<<100$ but $>65 \%)$ full as Class $4 ; 50 \%(<65$ but $>35 \%)$ full as Class $3 ; 25 \%(<35$ but $>5 \%)$ full as Class $2 ;<5 \%$ full or only a trace of food as Class 1 ; and empty stomach as Class 0 . Thereafter the stomach was teased and examined under a differential interference microscope. The relative contribution of each food item to the total stomach content was subjectively assessed on a 5-step scale of points: a food category representing 95 to $100 \%$ of stomach contents was given 100 points; $75 \%$ $(<95$ and $>65 \%), 75$ points; $50 \% \quad(<65$ and $>35 \%)$, 50 points; $25 \%(<35$ and $>5 \%), 25$ points; $5 \%$ or less, 2.5 points. The points for each food category were weighted by multiplying the value dependent on the class of stomach fullness (Class $5=1.0$; Class $4=0.75$; 
Class $3=0.5 ;$ Class $2=0.25 ;$ Class $1=0.02$ ). Finally, the number of points of each food item was expressed as a percentage of the total stomach contents.

Based on the composition of the stomach contents derived from the points method, an overlap index of diets was calculated intra- and interspecifically using the following equation (Schoener 1970):

$$
R o=100\left(1-\frac{1}{2} \sum_{i}\left|p x_{i}-p y_{i}\right|\right)
$$

where $R_{0}$ is the overlap index expressed as a percentage, and $p x_{i}$ and $p y_{i}$ are the relative importance (ratio of the points) of each food item $i$ in the stomachs of predator species $x$ and $y$

\section{RESULTS}

\section{Diel feeding rhythm}

\section{Archaeomysis kokuboi}

Diel changes in gut pigment contents and frequency occurrence of empty stomachs of Archaeomysis kokuboi are shown in Fig. 1. During the daytime (10:00 to 16:00 h) the gut pigment content of A. kokuboi fluctuated at a low level of around 5 to 10 and 2 to $4 \mathrm{ng} \mathrm{mg}^{-1}$ $\mathrm{C}$ for juvenile and mature mysids, respectively (Fig. 1a). At 19:00 h, just after sunset, the values increased drastically in all categories and thereafter fluctuated at a high level of over 100 and $50 \mathrm{ng} \mathrm{mg}^{-1} \mathrm{C}$ for juveniles and matures, respectively. The maximum value of $269.1 \mathrm{ng}$ $\mathrm{mg}^{-1} \mathrm{C}$ was observed in a juvenile at 19:00 $\mathrm{h}$ and was 4.2 and 3.2 times as high as those for mature males and females, respectively. After 01:00 h the values decreased gradually regardless of sex and developmental stage and by the next morning at 10:00 $\mathrm{h}$ they had decreased to $11.9,6.7$ and $4.9 \mathrm{ng} \mathrm{mg}^{-1} \mathrm{C}$ for juveniles, mature males and mature females, respectively.

The percentage of occurrence of empty stomachs in the total stomachs examined was high during the daytime, while no empty stomachs occurred at night (Fig, 1b). At 10:00 h, the occurrence rates of empty stomachs were $50.0,21.4$ and $41.7 \%$ for juveniles, mature males and mature females, respectively. Thereafter these values increased and reached a peak of over $90 \%$ at 16:00 h, just before sunset. The frequency of occurrence of empty stomachs, however, decreased to zero just after sunset at 19:00 h and this continued until just before sunrise at 04:00 h. At 07:00 h just after sunrise, empty stomachs occurred again at 29.7,7.7 and $5.0 \%$ of total stomachs examined for juveniles, mature males and mature females, respectively. Furthermore these values continued to increase to the same level as observed $24 \mathrm{~h}$ before at 10:00 $\mathrm{h}$.

\section{Archaeomysis japonica}

This species also shows the diel feeding rhythm, although it was not as clear as that of Archaeomysis kokuboi (Fig. 2). The mean gut pigment content values during the dark period (19:00 to 4:00 h), however, were significantly higher than the daytime values $10: 00$ to $16: 00$ and $07: 00$ to $10: 00 \mathrm{~h}$ ) in the 3 categories ( $t$-test, $\mathrm{p}<0.01$ ) (Fig. 2a). From 10:00 to 13:00 h, the gut pigment contents fluctuated at a low level below $5 \mathrm{ng}$ $\mathrm{mg}^{-1} \mathrm{C}$ regardless of sex and developmental stage, but these values began to increase at $16: 00 \mathrm{~h}$ with values of $19.2,9.6$ and $8.2 \mathrm{ng} \mathrm{mg}^{-1} \mathrm{C}$ for juveniles, mature males and females, respectively. In juveniles the gut pigment contents increased sharply after sunset and reached a peak of $207.0 \mathrm{ng} \mathrm{mg}^{-1} \mathrm{C}$ at 19:00 h. After 01:00 h the values decreased gradually down to the same level,
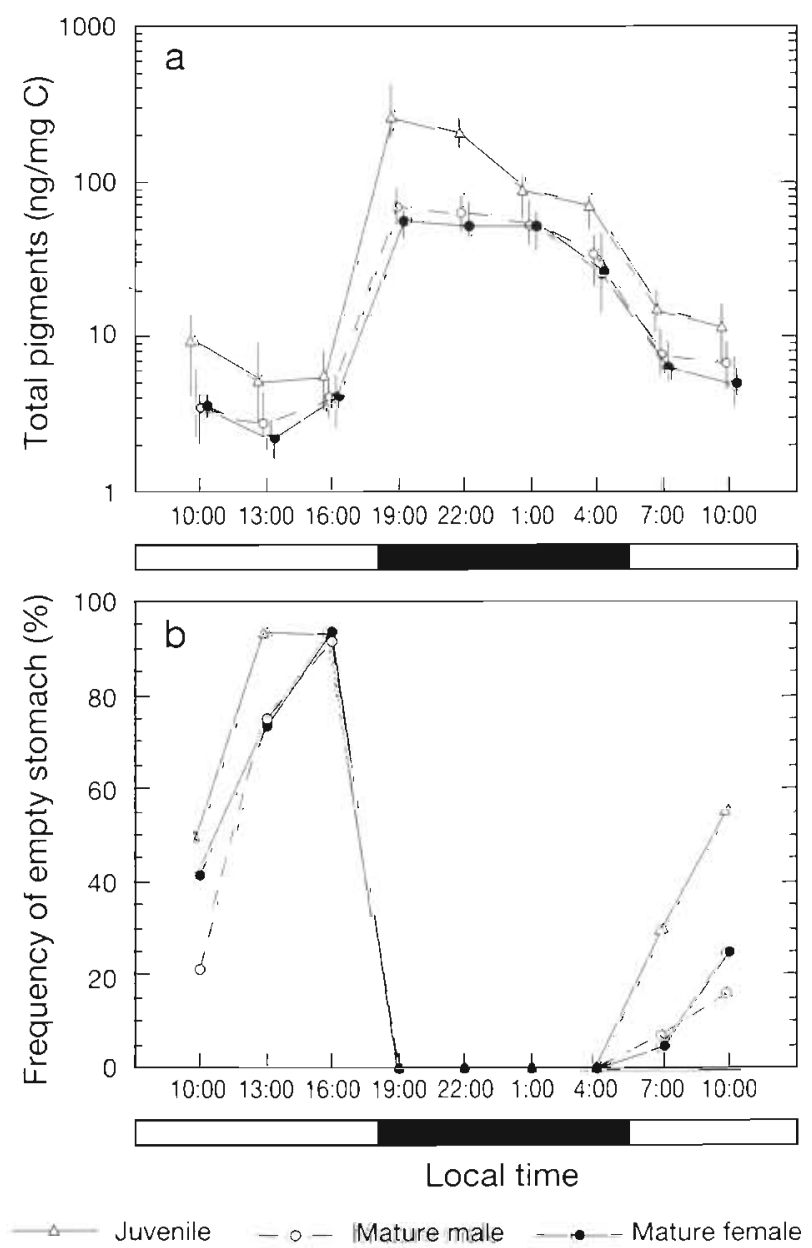

Fig. 1. Archaeomysis kokuboi. Diel change in the feeding intensity during the $24 \mathrm{~h}$ period, $8-9$ September 1994 . (a) Gut pigment expressed as total pigment weight (ng) per mysid body weight ( $\mathrm{mg} \mathrm{C}$ ). Vertical lines indicate the range of values. (b) Percentage of empty stomachs, 10 to 20 stomachs examined every $3 \mathrm{~h}$. Night period indicated by black area under the time axis 

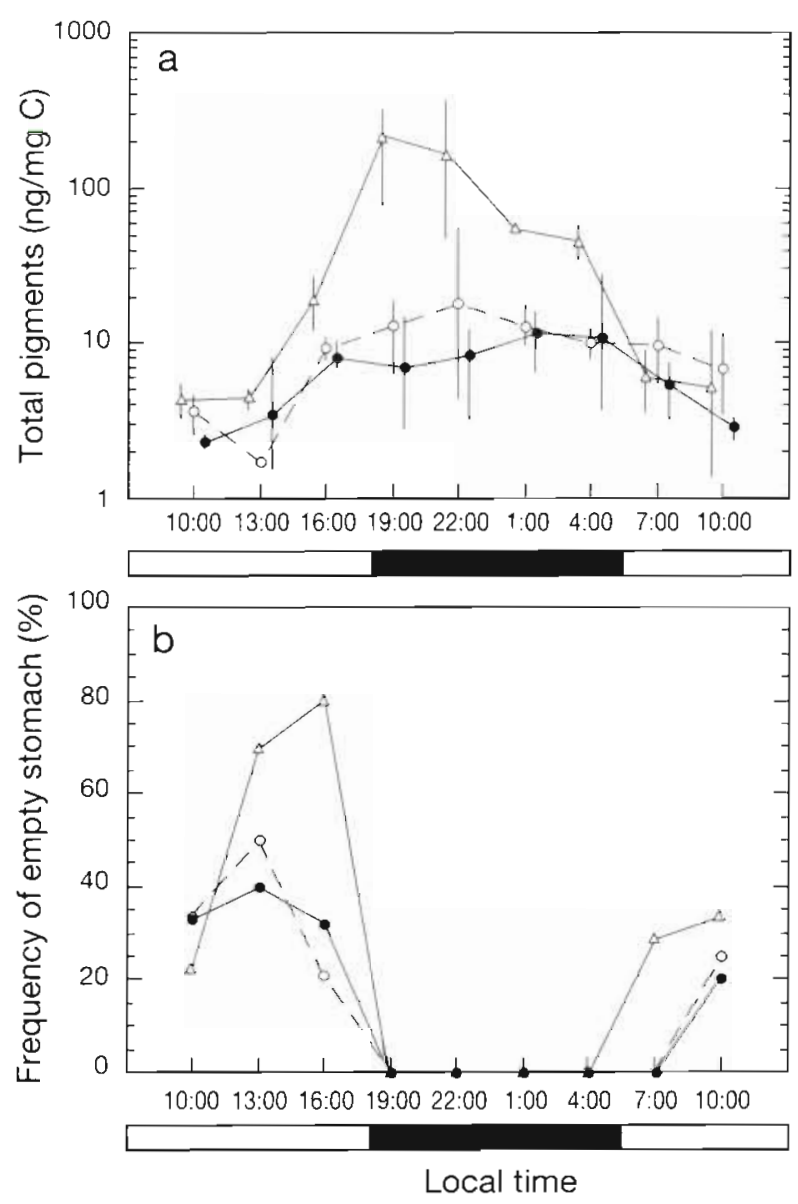

$\triangle-$ Juvenite $\quad-\circ-$ Mature male $\longrightarrow$ Mature female

Fig. 2. Archaeomysis japonica. Diel change in the feeding intensity during the $24 \mathrm{~h}$ period, 8-9 September 1994. (a) Gut pigment expressed as total pigment weight (ng) per mysid body weight $(\mathrm{mg} C)$. Vertical lines indicate the range of values. (b) Percentage of empty stomachs, 10 to 20 stomachs examined every $3 \mathrm{~h}$. Night period indicated by black area under the time axis

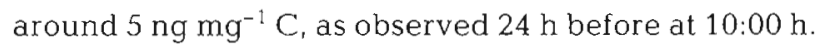
On the other hand, the nighttime increase in mature male and female values was not so drastic as observed in juveniles. At night the gut pigment contents of mature males and females fluctuated in the ranges 8.9 to 18.4 and 7.1 to $11.7 \mathrm{ng} \mathrm{mg}^{-1} \mathrm{C}$, respectively. The maximum value for juveniles was 11.3 and 17.9 times as high as those for mature males and females, respectively. These differences were larger than in A. kokuboi. Decreases in gut pigment content after sunrise were not so clear in mature males and females as in juveniles.

The percentage of empty stomachs in the total stomachs examined was high during the daytime, while no empty stomachs occurred at night as observed in Archaeomysis kokuboi (Fig. 2b). The fluctu- ation pattern of occurrence of empty stomachs was different between juveniles and adults. At 10:00 h the percentage of empty stomachs was 22.2, 33.3 and $33.3 \%$ for juveniles, mature males and mature females, respectively. Thereafter these values increased continuously to show a peak at 16:00 h just before sunset in juveniles, and a peak at 13:00 $\mathrm{h}$ in mature males and females (Fig. 2b). The percentage of empty stomachs decreased to zero at 19:00 h just after sunset in the 3 categories and remained zero until 04:00 h just before sunrise for juveniles, and until 07:00 h for adults (Fig. 2b). At 10:00 h the frequency of empty stomachs of both mature males and females reached about $20 \%$.

\section{Diets}

The stomach contents of Archaeomysis kokuboi and A. japonica were investigated using the night-collected samples captured between 19:00 and 04:00 h since they showed remarkably high nocturnal feeding activities. Their food items and their frequencies of occurrence are shown in Table 1 . Unidentified materials were detected in almost all of the stomachs in all categories of both species. These materials consisted of fine particulate matter and probably were well digested or macerated prey items.

\section{Archaeomysis kokuboi}

Relative composition of the stomach content of each developmental stage of Archaeomysis kokuboi was analyzed by the points method (Fig. $3 a, b, c$ ). The difference between sexes in the composition of stomach contents was not statistically significant (chi-square test, $\mathrm{p}>0.5$ ) and their overlap index of stomach contents was $77 \%$ (Table 2). The planktonic copepod Microsetella rosea was the most dominant species in the stomachs of the mature female and male (female: $44.3 \%$ of the stomach contents, male: $59.0 \%$ ). Oncaea venusta was the secondmost dominant species in the stomach contents of the mature female $(22.1 \%)$ and male $(17.7 \%)$. Other copepods, mainly consisting of planktonic species such as Acartia, Oithona and Pseudocalanus, occupied $14.2 \%$ of the stomach contents of the female but $0.2 \%$ in the male. Copepod nauplii occupied only $2.7 \%$ and $9.1 \%$ of the female and male stomach contents, respectively. These planktonic copepods seem to be a major food of adult $A$. kokuboi. Dinoflagellates such as Prorocentrum spp. and Ceratium spp. frequently occurred in the adult stomach (Table 1), but do not seem quantitatively important (Fig. 3a, b). The composition of stomach contents in juvenile $A$. kokuboi is significantly different 
Table 1. Archaeomysis kokuboi and A. japonica. Food items and their frequency of occurrence in percentage of total number of stomachs examined. - not detected. $\mathrm{n}$ = number of stomachs examined

\begin{tabular}{|c|c|c|c|c|c|c|c|}
\hline \multirow[t]{2}{*}{ Food item } & \multirow{2}{*}{$\begin{array}{l}\text { Abbreviation } \\
\text { in Fig. } 3\end{array}$} & \multicolumn{3}{|c|}{ Archaeomysis kokuboi } & \multicolumn{3}{|c|}{ Archaeomysis japonica } \\
\hline & & $\begin{array}{l}\text { Female } \\
(\mathrm{n}=30)\end{array}$ & $\begin{array}{c}\text { Male } \\
(\mathrm{n}=34)\end{array}$ & $\begin{array}{l}\text { Juvenile } \\
(\mathrm{n}=34)\end{array}$ & $\begin{array}{l}\text { Female } \\
(\mathrm{n}=31)\end{array}$ & $\begin{array}{c}\text { Male } \\
(n=28)\end{array}$ & $\begin{array}{l}\text { Juvenile } \\
(\mathrm{n}=25)\end{array}$ \\
\hline \multicolumn{8}{|l|}{ Crustaceans } \\
\hline Microsetella rosea & MR & 87 & 100 & - & 56 & 36 & 4 \\
\hline Oncaea venusta & OV & 60 & 17 & - & 31 & 7 & - \\
\hline Other copepods & $\mathrm{OC}$ & 30 & 9 & _- & 25 & 28 & _- \\
\hline Benthic harpacticoids & $\mathrm{BH}$ & 3 & 3 & - & 66 & 60 & - \\
\hline Copepod nauplii & $C N$ & 50 & 56 & 30 & 44 & 16 & 48 \\
\hline Crustacean fragments & CF & 27 & 34 & 70 & 47 & 60 & 70 \\
\hline \multicolumn{8}{|l|}{ Dinoflagellates } \\
\hline Prorocentrum spp. & & 67 & 75 & 18 & 19 & 7 & 8 \\
\hline Ceratium spp. & DF & 37 & 44 & 24 & 3 & - & 26 \\
\hline Perdinium spp. & & 10 & 6 & 3 & - & - & 11 \\
\hline Tintinnids & $\mathrm{TT}$ & 10 & 9 & 15 & - & - & 11 \\
\hline Diatoms & DT & 3 & - & 3 & - & 7 & - \\
\hline \multicolumn{8}{|l|}{ Others } \\
\hline Foraminiferans & & 3 & - & - & - & - & - \\
\hline Cysts & OT & - & - & - & - & - & 11 \\
\hline Mollusca larvae & & 3 & - & - & - & - & - \\
\hline Spicule of sponge & & - & - & - & - & 7 & - \\
\hline Unidentified materials & UM & 93 & 94 & 100 & 81 & 100 & 100 \\
\hline
\end{tabular}

from that of mature females and males (chi-square test, $p<0.01$; Fig. 3c). The intraspecific overlap indices of the stomach contents were low between juveniles and mature males and females, being 21 and $16 \%$, respectively (Table 2). Crustacean fragments were the most dominant food item in the juvenile stomachs (30.0\%) except for the unidentified materials, which were judged to originate from copepod nauplii (14.0\%), since other crustacean taxa rarely occurred in the stomachs. Dinoflagellates, such as Prorocentrum spp. and Ceratium spp., and tintinnids were also detected with rather high frequency (Table 1), but their importance is thought to be very low because of the low percentage values of relative contribution to the total stomach contents (Fig. 3c).

\section{Archaeomysis japonica}

Relative composition of stomach contents of each developmental stage of Archaeomysis japonica assessed by the points method is shown in Fig. 3d, e and $f$. The difference between sexes in the composition was not statistically significant (chi-square test, $\mathrm{p}>0.5$ ) and the overlap index of diets was $75 \%$ (Table 2 ). Benthic harpacticoid copepods were the most dominant food item in the mature male and female stomachs $(36.5 \%$ : female, $30.4 \%$ : male). Planktonic copepods followed the benthic copepods in percent composition, i.e. Microsetella rosea (female: $24.8 \%$; male: $21.6 \%$ ), Oncaea venusta (female: $7.5 \%$, male: $2.8 \%$ ), other planktonic copepods (female: $8.6 \%$, male: $6.0 \%$ ), and copepod nauplii (female: $9.0 \%$, male: $0.5 \%$ ). Crustacean fragments which probably originated from the crustaceans listed above were also detected at 7.4 and $19.3 \%$ in the mature male and female stomachs, respectively. Dinoflagellates were scarce in the adult stomachs, in striking contrast to $A$. kokuboi (Table 1, Fig. 3d, e). The composition of stomach contents of juvenile $A$. japonica was significantly different from those of mature females and males (chi-square test, $p<0.01$ ) and intraspecific overlap indices of the diets between juveniles and mature females and males were 25 and $41 \%$, respectively (Table 2). Copepod nauplii were a particularly dominant food item in the juvenile stomachs $(29.1 \%)$ except for the unidentified materials. Crustacean fragments which probably originated from copepod nauplii represented $28.0 \%$ of the stomach contents. Dinoflagellates were more frequently found in juvenile stomachs compared with adults (Table 1) and occupied $3.1 \%$ of the stomach contents (Fig. 3f).

Table 2. Archaeomysis kokuboi and A. japonica. Intraspecific overlap indices $(R o)$ of diets

\begin{tabular}{|lcc|}
\hline Developmental stage & A. kokuboi & A. japonica \\
\hline Mature male vs mature female & 77 & 75 \\
Juvenile vs mature female & 21 & 25 \\
Juvenile vs mature male & 16 & 41 \\
\hline
\end{tabular}




\section{Archaeomysis kokuboi}

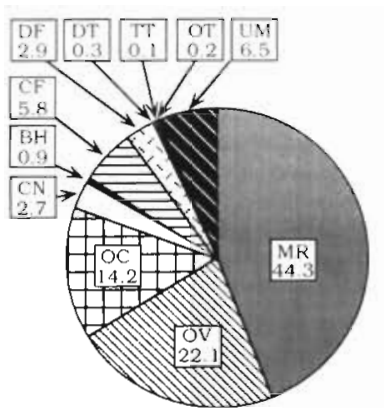

a: Mature female $(n=30)$

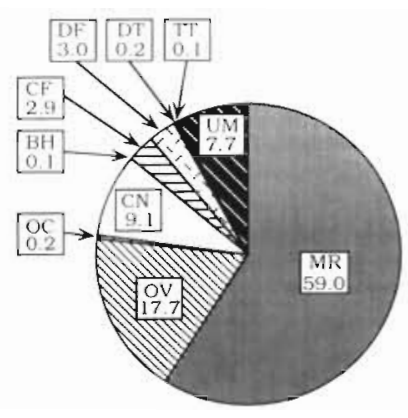

b: Mature male $(n=34)$

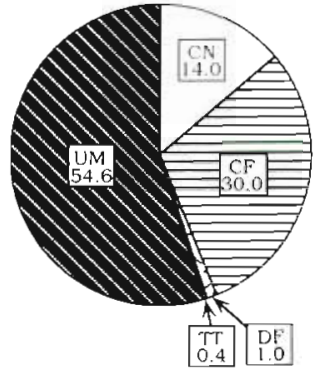

c: Juvenile $(n=34)$

\section{Archaeomysis japonica}

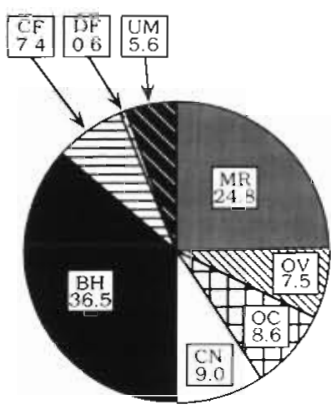

d: Mature femalc $(n=31)$

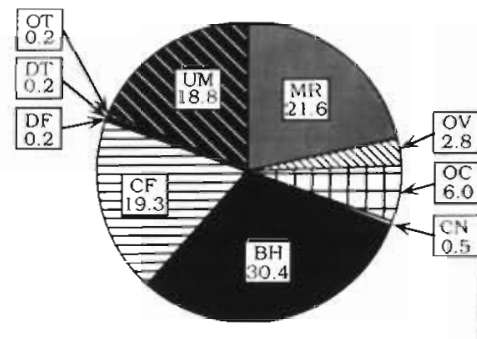

c: Mature male $(n=28)$

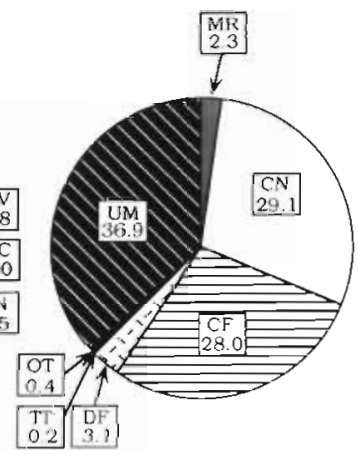

f: Juvenik $(n=25)$
Fig. 3. Relative composition of stomach contents of $(\mathrm{a}-\mathrm{c})$ Archaeomysis kokuboi and (d-f) $A$. japonica. (a,d) Mature female, (b, e) mature male, (c,f) juvenile. Stomach contents expressed as a percentage using the point method (see 'Materi. als and methods'). See Table 1 for abbreviations of food items. $n$ : number of stomachs examined
Overlap indices of stomach contents were calculated between the 2 species and shown in Table 3 . The highest value of $80 \%$ was observed between the juveniles of the 2 species. The value between female Archaeomysis kokuboi and female $A$. japonica was $56 \%$, and between female $A$. kokuboi and male A. japonica was $51 \%$. The other combinations resulted in values between 19 and $45 \%$ (Table 3).

\section{DISCUSSION}

Archaeomysis kokuboi showed pronounced nocturnal feeding. Their feeding activity became high just after sunset and maintained the high level until just before sunrise. It is known that many mysid species, such as Gastrosaccus psammodytes, Siriella pacifica, Mysis relicta, Neomysis integer and $M$. mixta, exhibit distinct nocturnal feeding behaviors (Brown \& Talbot 1972 . Hobson \& Chess 1976, Grossnickle 1979, Bremer \& Vijverberg 1982, Rudstam et al. 1989). Some mysids, however, such as Acanthomysis sculpa
Table 3. Archaeomysis kokuboi and A. japonica. Intraspecific overlap indices $(R O)$ of diets

\begin{tabular}{|lccc|}
\hline Archaeomysis japonica & \multicolumn{3}{c|}{ Archaeomysis kokuboi } \\
& Mature female & Mature male & Juvenile \\
\hline Mature female & 56 & 45 & 23 \\
Mature male & 51 & 36 & 39 \\
Juvenile & 19 & 24 & 80 \\
\hline
\end{tabular}


kokuboi are planktonic copepods such as Microsetella rosea or Oncaea venusta for the mature mysids and copepod nauplii for the juveniles. Itô (1985) reported that a sand-burrowing mysid in the swash zone of subarctic northern Japan exclusively feeds on Microsetella norvegica, which is closely related to $M$. rosea, and suggested the possibility that $M$. norvegica was transported from the offshore areas to the swash zone through the physical processes. Nath \& Pillai (1973) found copepods, diatoms and dinoflagellates in the stomach of the intertidal sand-burrowing mysid $G$ simulans from the Indian coast. These observations show that the planktivorous feeding habit seems to be very common in the intertidal sand-burrowing mysids. The feeding behavior of $A$. kokuboi, i.e. nocturnal planktivorous feeding in the swash zone, is thought to be advantageous for effective utilization of the rich food source, planktonic organisms continuously transported from the offshore area. Recently, in planktonic organisms, turbulence has been considered as an important factor for increasing the predator-prey contact rate (e.g. Osborn \& Scotti 1996) and thus the turbulent environment of the swash zone may provide good feeding conditions for the mysids. This behavior may also be effective in decreasing the disadvantages of predation and waste of swimming energy, which are present outside of the swash zone. This feeding behavior of $A$. kokuboi, involving adaptation to the swash zone, may help sustain their higher biomass than that of $A$. japonica.

Archaeomysis japonica also exhibited nocturnal feeding but the diel rhythm was not so clear as observed in $A$. kokuboi, especially in adults. Increase in the gut pigment contents of the adult stages was observed from 13:00 to $16: 00 \mathrm{~h}$, before sunset. It fluctuated around the same level during the nighttime and decreased gradually from 01:00 h.

Accordingly the adult mysids with empty stomachs began to increase at $10: 00 \mathrm{~h}$, reached a peak at 13:00 $\mathrm{h}$ and decreased after this time. Empty stomachs did not occur from 19:00 to 07:00 h. These phenomena suggest that the feeding period of mature $A$. japonica is not always restricted to the dark period or that the gut evacuation time was longer than that of $A$. kokuboi and juvenile $A$. japonica. The feeding rhythm of juveniles was much clearer than that of adults, i.e. their feeding was limited to the dark period. This suggests that the feeding time of $A$. japonica extends to the daytime with growth and would explain the inconsistency observed at 16:00 h in the juveniles, i.e. the increase of frequency of empty stomachs and the gut pigment contents, probably due to the individual differences of feeding intensity of juveniles at various growth stages. It is interesting that mature A. japonica feed well on benthic harpacticoid cope- pods together with planktonic copepods. Benthic copepods have been reported to actively swim up into the water column at night but most of them remain close to the bottom, within $10 \mathrm{~cm}$ or so (Alldridge \& King 1980, 1985, Madhupratap et al. 1991). As mature A japonica also have been known to be distributed in the water column 0 to $20 \mathrm{~cm}$ above the bottom at night (Takahashi \& Kawaguchi 1997), they can exploit both benthic and pelagic organisms opportunistically just above the bottom at night.

Juveniles of both species showed pronounced nocturnal feeding behaviors and the maximum values of gut pigment contents were similar. Moreover, the main diets of the juveniles of both species are common, namely copepod nauplii. On the other hand, copepods such as Microsetella rosea, Oncaea venusta or benthic harpacticoids, which are the main food items of their adults, scarcely occurred in the stomachs of juveniles of both species, probably due to their larger size spectra. The change in the species or size spectra of diets with growth has also been reported in other mysids such as Neomysis mercedis and Mysis relicta (Kost \& Knight 1975, Cooper \& Goldman 1980, Siegfried \& Kopache 1980, Murtaugh 1981, Johnston \& Lasenby 1982). The overlap index of the stomach contents between juveniles of both species was very high, accounting for $80 \%$. On Koshirahama Beach the small individuals ( $<3 \mathrm{~mm} \mathrm{SL}$ ) of 3 species of sand-burrowing mysids, namely the 2 species studied here and the less abundant liella ohshimai, swim up into water column actively at night, but their spatio-temporal distributions do not overlap each other (Takahashi \& Kawaguchi 1997). This habitat segregation may be a good adaptation to interspecific food resource partitioning since their diets widely overlap each other.

The gut pigment method has been rarely employed in feeding studies of mysids, since almost all of them are considered as omnivorous feeders (Mauchline 1980 ). But the results of this study and some previous studies prove that it is effective for detecting the feeding rhythm of rather carnivorous mysids as well as herbivorous mysids since most of their diets contain herbivorous zooplankton (Grossinickle 1979, Rudstam et al. 1989). The gut pigment method, together with direct observation of stomach emptiness (or fullness), would lead to better detection of the feeding rhythm of mysids.

Temporal change in distribution patterns of prey organisms might affect stomach contents of the mysids and the quantification of this is the next step. However, the results of this study adequately demonstrate the general features of feeding habit of the sandburrowing mysids.

It was revealed that Archaeomysis kokuboi and $A$. japonica have a nocturnal feeding rhythm in all devel- 
opmental stages. This suggests that their speciesspecific distribution patterns during the daytime such as intraspecific zonation and tidal migration (Takahashi \& Kawaguchi 1995, 1997) would not be explained based on their feeding strategies, but instead based on predation avoidance, since Wooldridge (1981) reported that predator avoidance is one of the important factors in determining the distribution pattern of the intertidal sand-burrowing mysid Gastrosaccus psammodytes.

The swash zone of a sandy beach is considered as a 'high-energy window' since it receives a variety of organic materials from the sea such as macrophyte wrack, dead animals, and dissolved and particulate organic matter flushed through the sand during the process of seawater filtration (Riedle 1971, McIntyre \& Murison 1973, Hayes 1974, McLachlan 1983). Itô (1985) suggested that a sandy beach and its inhabitants function as a big natural purifier and intertidal sand-burrowing mysids play a role as the 'receptionist' of such organic materials. The planktivorous feeding habits of Archaeomysis kokuboi revealed here strongly support his view. On the other hand A. japonica may play a role as a 'mediator' between the water column and bottom through their opportunistic feeding on both pelagic and benthic organisms.

Acknowledgements. We are most grateful to Captain K Morita and Messrs T. Kawamura and K. Hirano of the Otsuchi Marine Research Center, Ocean Research Institute for their help in the field sampling. We thank Dr J Mauchline of the Dunstaffnage Marine Research Laboratory and the anonymous referees for critical reading of the manuscript. Thanks are also due to Dr T. P. Hirose and other staff of the plankton laboratory of O.R.I. for help in the field work and the fruitful discussion during the course of this study.

\section{LITERATURE CITED}

Alldredge AL, King, JM (1980) Effects of moonlight on the vertical migration patterns of demersal zooplankton. J Exp Mar Biol Ecol 44:133-156

Alldredge AL, King JM (1985) The distance demersal zooplankton migrate above the benthos: implications for predation. Mar Biol 84:253-260

Bremer P, Vijverberg J (1982) Production, population biology and diet of Neomysis integer (Leach) in a shallow Frisian lake (The Netherlands). Hydrobiologia 93:41-51

Brown AC, Talbot MS (1972) The ecology of the sandy beaches of the Cape Peninsula, South Africa. Part 3, a study of Gastrosaccus psammodytes Tattersall (Crustacea, Mysidacea). Trans R Soc S Afr 40:309-333

Clutter RI (1967) Zonation of nearshore mysids. Ecology 48 : 200-208

Cooper SD, Goldman CR (1980) Opossum shrimp (Mysis relicta) predation on zooplankton. Can J Fish Aquat Sci 37:909-919

Grossnickle NE (1979) Nocturnal feeding patterns of Mysis relicta in Lake Michigan, based on gut fluorescence. Limnol Oceanogr 24:777-780
Hanamura $Y$, Jo SG, Murano $M$ (1996) A new species of Archaeomysis from coastal waters of Japan (Mysidacea: Gastrosaccinae). Crustaceana 69:553-566

Hayes WB (1974) Sand-beach energetics, importance of the isopod Tylos punctatus. Ecology 55:838-847

Hobson ES, Chess JR (1976) Trophic interactions among fishes and zooplankters near shore at Santa Catalina Island, California. Fish Bull US 74:567-598

Itô $I$ (1985) Organisms in sand interstices. Kaimei Sha, Tokyo (in Japanese)

Jo SG, Hanamura Y (1993) Redescription of mysid Archaeomysis vulgaris (Nakazawa, 1910) Comb. Nov. (Crustacea: Mysidacea: Gastrosaccinae). Korean J Syst Zool 9:103-113

Johnston NT, Lasenby DC (1982) Diet and feeding of Neomysis mercedis Holms (Crustacea, Mysidacea) from the Fraser River Estuary, British Colombia. Can J Zool 60: 813-824

Kost ALB, Knight AW (1975) The food of Neomysis mercedis Holms in the Sacramento-San Joaquin estuary. Calif Fish Game 61:35-46

Mackas D, Bohrer R (1976) Fluorescence analysis of zooplankton gut contents and an investigation of diel feeding patterns. J Exp Mar Biol Ecol 25:77-85

Madhupratap M, Achuthankutty CT, Sreekumaran Nair SR (1991) Zooplankton of the lagoons of the Laccadives, diel patterns and emergence. J Plankton Res 13:947-958

Mauchline J (1980) The biology of mysids and euphausiids. Adv Mar Biol 18:1-681

Mauchline J, Murano M (1977) World list of Mysidacea, Crustacea. J Tokyo Univ Fish 64:39-88

McIntyre AD, Murison DJ (1973) The meiofauna of a flatfish nursery ground. J Mar Biol Assoc UK 53:93-118

McLachlan A (1983) Sandy beach ecology - a review. In: McLachlan A, Erasmus T (eds) Sandy beaches as ecosystems. Junk Publishers, The Hague, p 321-380

Murtaugh PA (1981) Size-selective predation on Daphnia by Neomysis mercedis. Ecology 62:894-900

Nath CN, Pillai NK (1973) The alimentary system of the littoral mysid Gastrosaccus simulans (Van Beneden). J Mar Biol Assoc India 15:577-586

Osborn T, Scotti A (1996) Effect of turbulence on predatoryprey contact rates: where do we go from here? Mar Ecol Prog Ser 139:302-304

Riedl RJ (1971) How much seawater passes through sandy beaches? Int Revue Ges Hydrobiol 56:923-946

Rudstam LG, Danielsson K, Hansson S, Johansson S (1989) Diel vertical migration and feeding patterns of Mysis mixta (Crustacea, Mysidacea) in the Baltic Sea. Mar Biol 101:43-52

Schoener TW (1970) Nonsynchronous spatial overlap of lizards in patchy habitats. Ecology 51:408-418

Siegfried CA, Kopache ME (1980) Feeding of Neomysis mercedis (Holms). Biol Bull (Woods Hole) 159:193-205

Suzuki R, Ishimaru T (1990) An improved method for the determination of phytoplankton chlorophyll using $\mathrm{N}, \mathrm{N}$ dimethylformamide. J Oceanogr Soc Jpn 46:190-194

Takahashi K (1996) Ecology of sand-burrowing mysids in Otsuchi Bay, northeastern Japan. PhD thesis, University of Tokyo (in Japanese)

Takahashi K, Kawaguchi K (1995) Inter- and intraspecific zonation in three species of sand-burrowing mysids, Archaeomysis kokuboi, A. grebnitzkii and Iiella ohshimai, in Otsuchi Bay, northeastern Japan. Mar Ecol Prog Ser 116:75-84

Takahashi K, Kawaguchi K (1996) Practical key characters to identify the closely related sand-burrowing mysids, Archaeomysis kokuboi and A. japonica (Mysidacea; Gas- 
trosaccinae) throughout all developmental stages. Bull Plankton Soc Jpn 43:133-137

Takahashi K, Kawaguchi K (1997) Diel and tidal migrations of the sand-burrowing mysids, Archaeomysis kokuboi, $A$. japonica and liella ohshimai, in Otsuchi Bay, northeastern Japan. Mar Ecol Prog Ser 148:95-107

Wear RG, Haddon M (1987) Natural diet of the crab Ovalipes catharus (Crustacea, Portunidae) around central and northern New Zealand. Mar Ecol Prog Ser 35:39-49

Webb P, Perissinotto R, Wooldridge TH (1988) Diet and feeding of Gastrosaccus psammodytes (Crustacea, Mysidacea) with special reference to the surf diatom Anaulus birostratus. Mar Ecol Prog Ser 45:255-261

Webb P, Wooldridge TH (1990) Diel horizontal migration of

Editorial responsibility: Otto Kinne (Editor),

Oldendorf/Luhe, Germany
Mesopodopsis slabberi (Crustacea, Mysidacea) in Algoa Bay, southern Africa. Mar Ecol Prog Ser 62:73-77

Williams MJ (1981) Methods for analysis of natural diet in portunid crabs (Crustacea: Decapoda: Portunidae). J Exp Mar Biol Ecol 52:103-113

Wooldridge $T$ (1981) Zonation and distribution of the beach mysid, Gastrosaccus psammodytes (Crustacea, Mysidacea). J Zool Lond 193:183-189

Wooldridge TH (1989) The spatial and temporal distribution of mysid shrimps and phytoplankton accumulations in high energy surf zone. Vie Milieu 39:127-133

Yentsch CS, Menzel D (1963) A method for the determination of phytoplankton chlorophyll and phaeophytin by fluorescence. Deep Sea Res 10:221-231

Submitted: April 4, 1997; Accepted: November 17, 1997

Proofs received from author(s): January 23, 1998 